\title{
Adsorption of Jumputan liquid waste by betel nuts activated carbon in a continuous fixed-bed adsorber
}

\author{
Lia Cundari* , Aris Setiawan Kemit, and Baharuddin Rasyid Usman \\ Chemical Engineering Department, Faculty of Engineering, Universitas Sriwijaya, 30139 Inderalaya, Indonesia
}

\begin{abstract}
Jumputan is one of South Sumatera art crafts that increasingly produced by textile industries in the region. Dyeing and washing process are applied in jumputan production that will contribute to the increase of chemical content in waste water. This research will address the solution to this problem by investigating the waste water treatment using continuous adsorption process with activated carbon made from betel nuts as an adsorbent. Activated carbon was produced at carbonization temperature $500^{\circ} \mathrm{C}$ and activated by $0.5 \mathrm{M} \mathrm{HCl}$ and sized 18 mesh sieve. Adsorption was performed using Fixed-bed adsorber made from fiberglass with $100 \mathrm{~cm}$ height and $10 \mathrm{~cm}$ diameter. Jumputan liquid waste was fed from the top of the column at $58 \mathrm{~mL} / \mathrm{min}$. The height of bed was varied at $5,15,25 \mathrm{~cm}$ and sampling time was performed in $30,60,90,120,150 \mathrm{~min}$ to determine COD reduction. Optimum condition of this process is $25 \mathrm{~cm}$ of bed height and $150 \mathrm{~min}$ of sampling time that reduces COD value of waste water to $99.69 \%$.
\end{abstract}

\section{Introduction}

South Sumatera province especially Palembang, has popular art crafts such as songket, jumputan, and wood cabinets craved. One of craft that intensively industrialized is jumputan, a well-known fabric with traditional painting. People used to wear jumputan not only in a ceremonial occasion but also in daily life. Fabrication of jumputan involves dyeing and washing process. Dyeing process utilizes synthetic dyes, such as Napthol, Indigosol, Rapide, Ergan Soga, Kopel Soga, Chroom Soga, and Procion [1]. Synthetic dyes were preferable than natural due to its low cost, durability and diverse of colours.

Dyeing and washing processes bring out liquid waste that contains hazardous chemicals. If that liquid waste directly discharged into the river, it will cause environmental pollution. According to Minister of Environment pursuant regulation No. 5 of 2014 on the quality of raw sewage, the water discharged into water bodies must be below the threshold [2]. In the fabrication of jumputan lots of liquid waste has resulted because some of the synthetic dyes can not be absorbed by jumputan textile. The waste is dumped into Musi river which can cause damage to ecosystems that exist in the river. These synthetic dyes will reduce oxygen demand that water organism needed.

Musi River turbidity has doubled exceeding the maximum allowable turbidity [3]. According to [4], maximum allowable turbidity is 600 NTU. Turbidity is caused by the disposal of wastewater from domestic and industrial, as well as sedimentation of solid particles that lead to settling of Musi river.
Besides turbidity, the degree of water quality also can be reflected from the content of chemical oxygen demand (COD), biological oxygen demand (BOD), total suspended solid (TSS), and the content of chrome, phenols, ammonia, sulfides and oil/fats [2]. COD is the amount of oxygen consumed by organic compounds and inorganic matter which were oxidized in water [5]. Lots of organic and inorganic matter indicates higher COD that means a bad water quality.

Various methods have been developed to treat liquid waste like coagulation-flocculation [6], advanced oxidation process [6], mechanical filtration, adsorption, ion exchange and membrane systems. One of wastewater treatment technology that was cheap, easy to obtain, easy to operate, and effective is adsorption. Adsorption is a process to absorb contaminant in the feed with solid material as an adsorbent. The contaminant accumulates on the surface of the adsorbent. There are a lot of factors that influence adsorption processes, such as surface area contact of adsorbent, type of the feed, molecules structure and concentration of the feed, temperature operation, $\mathrm{pH}$, agitation speed (for a batch system), and contact time between feed and adsorbent. Widely adsorbent that uses in many adsorption process is activated carbon.

Activated carbon based on organic materials that used in large and small industries either as a catalyst, deodorizing, absorption color, substance purification and so on. Activated carbon as adsorbent has been widely studied, either in a pure state [7], [8], [9], [10], [11], [12], [13], [14], [15], [16]; or combined with other ingredients [17].

\footnotetext{
* Corresponding author: icun hyang02@yahoo.com
} 
Yuliasari et al (2011) removed COD on Jumputan wastewater by using lumut hati powder. COD value analyzed with spectrophotometry method. 100 mesh lumut hati powder contacted with $50 \mathrm{~mL}$ waste media. Variation of mass lumut hati $(5,15,23,35$, and $50 \mathrm{mg})$ was made. The mixture was shaken at $150 \mathrm{rpm}$ for 60 minutes and after that settled for 10 minutes. The filtrate was taken and analyzed. Optimum condition was 60 minutes operation and $25 \mathrm{mg}$ lumut hati powder, COD reduced from $193.5 \mathrm{mg} / \mathrm{L}$ to $48.69 \mathrm{mg} / \mathrm{L}$ or $74.84 \%$ COD reduction [10].

Batch investigation on jumputan wastewater treatment by using activated carbon, zeolite, and fenton reagent, within 30 minutes operation, COD reduction was $38 \%$ and color degradation was $10 \%$ [9]. The effect of temperature and time on procion synthetic wastewater treatment with fenton reagent was studied. This process called advanced oxidation processes (AOPs) method. Red and blue procion synthetic dyes were used with concentration 150-250 mg/L, agitation $200 \mathrm{rpm}$, Fenton reagent concentration $\mathrm{H}_{2} \mathrm{O}_{2} 80 \mathrm{mM}$ and $\mathrm{FeSO}_{4} .7 \mathrm{H}_{2} \mathrm{O} 4$ $\mathrm{mM}$, pH 3, agitation time $0-60$ minutes, and temperature $25-55^{\circ} \mathrm{C}$. This article reported $100 \%$ dye degradation could be obtained in temperature $55^{\circ} \mathrm{C}$ and 60 minutes agitation time. That condition was applicated to jumputan wastewater. For $100 \%$ dye degradation, optimum condition was at temperature $55^{\circ} \mathrm{C}$ and agitation time 120 minutes with reduced COD 66\% [1].

Cundari et al (2015) conducted preliminary research by using betel nuts activated carbon to adsorb jumputan wastewater in a batch system. Researchers analyzed the best betel nuts activated carbon that could adsorb jumputan wastewater. The temperature carbonization and $\mathrm{HCl}$ concentration were varied. The carbonization temperature was $400^{\circ} \mathrm{C}, 500^{\circ} \mathrm{C}$, and $600^{\circ} \mathrm{C}$ with $\mathrm{HCl}$ concentration $0.1 \mathrm{M}, 0.3 \mathrm{M}$, and $0.5 \mathrm{M}$. This research reported the optimum carbonization temperature was $500^{\circ} \mathrm{C}$ with $0.5 \mathrm{M} \mathrm{HCl}$ concentration. The results showed $98.61 \%$ reduction in COD; $98.50 \%$ reduction in BOD; $87.50 \%$ reduction in TSS; and $96.30 \%$ reduction in Chrome.

Most research on activated carbon is done in the batch system, only a few are using continuous flow fixed bed adsorber. The data obtained by a batch system is inapplicable to get the equilibrium data due to insufficient time (Uddin, et.al. in [11]). The equilibrium data of absorption the basic red 46 (BR46) using granular activated carbon (12-40 mesh (0.425 to 1.70 $\mathrm{mm})$ ) in a fixed-bed column reported [11] indicates that Freudlich isotherm model is more suitable than Langmuir. They use a column with the following dimensions: inside diameter $=12 \mathrm{~mm}$, height of column $210 \mathrm{~mm}$, the height of bed $100 \mathrm{~mm}$, and flow rate 50 $\mathrm{mL} / \mathrm{min}$.

Gimenes (2013) also reported on a continuous adsorption. The copper absorption by using bentonite $(0.855 \mathrm{~mm})$ in regenerable Calcined Clay Column. Acrylic column dimensions are: inside diameter $=1.4$ $\mathrm{cm}$, the height of column $24 \mathrm{~cm}$, height of bed $14 \mathrm{~cm}$, and flow rate $4 \mathrm{~mL} / \mathrm{min}$. The test resulted that the adsorption process using a fixed-bed column was promising but still requires further investigation to determine its technical and economical feasibility.

The type of adsorbent used in this study is activated carbon made from betel nuts. The preliminary assessment of the jumputan wastewater treatment using betel nuts activated carbon had been conducted in a batch process [7]. Wastewater treatment required a comprehensive system and operated continuously. Compared to batch process, continuous treatment is more applicable due to time efficiency, low operating cost, and quantity of wastewater that can be treated [18].

This research will examine chemical oxygen demand (COD) degradation in jumputan wastewater treatment by using continuous fixed-bed adsorber with the various height of bed and sampling time. Aims of this research are to improve the quality Musi river, due to continuously increased turbidity, up to double maximum turbidity numbers [3], and to get appropriate technology for processing jumputan liquid waste that can be directly installed and used by craftsmen.

\section{Experimental Details}

Betel nuts activated carbon was produced at $500{ }^{\circ} \mathrm{C}$ carbonization temperature and activated using $0.5 \mathrm{M}$ $\mathrm{HCl}$ concentration based on the method by [7]. Jumputan liquid waste is taken from jumputan crafting area in Kertapati, Palembang. Figure 1 illustrates schematic of apparatus for adsorption process.

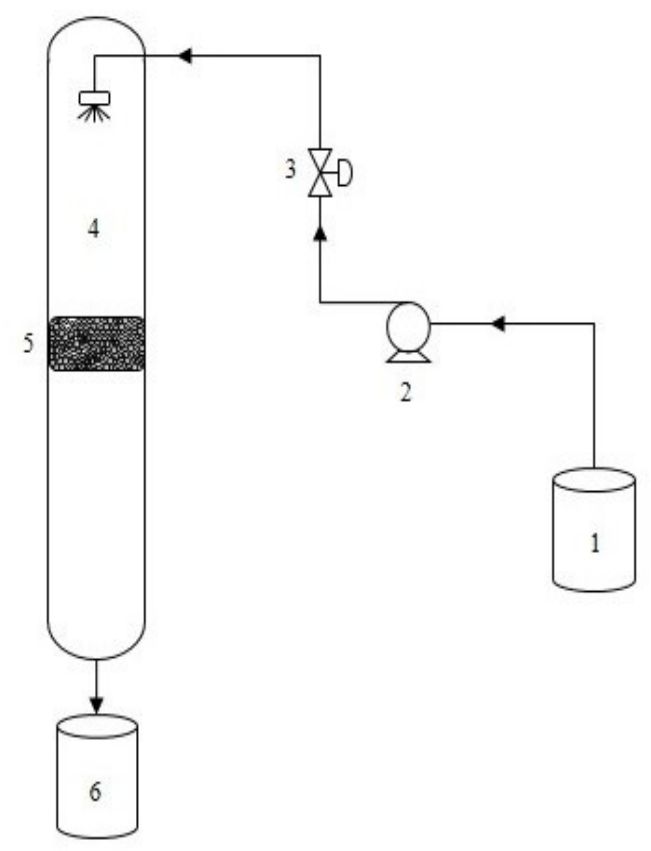

Fig.1. Schematic Apparatus of Adsorption Process

Description:

1) Jumputan Liquid Waste Tank

2) Pump

3) Valve

4) Continuous Fixed Bed Adsorber

5) Bed

6) Outlet Tank 
Betel nuts activated carbon was sieved to 18 mesh and was placed inside the continuous fixed-bed adsorber. The dimension of the column was $10 \mathrm{~cm}$ diameter and $100 \mathrm{~cm}$ height. The height of bed varies from 15, 25, and $35 \mathrm{~cm}$. Another variable is sampling time that varied in $30,60,90,120$, and 150 minutes. Volumetry method is used to analyze COD of liquid in the outlet tank.

Jumputan liquid waste in the tank (1) is filtered and then pumped to the top of the adsorber. The inlet will be distributed into the column by using a sprayer. Adsorber (4) which is used in this study is a fixed bed type, wherein the adsorbent is placed permanently in the bed. This bed (5) is placed in the middle column. The adsorption process is carried out continuously. Because of that, this apparatus calls continuous fixed-bed adsorber.

After the mass transfer between jumputan liquid waste and adsorbent, the content of dye, biological, chemical, and heavy metals will be absorbed by the adsorbent. Outlet liquid will be removed from the bottom of the column to the storage tanks (6). The samples are taken from the outlet with variation sampling time and analyzed. This study examines chemical oxygen demand in the samples.

\section{Results and Discussion}

The quality of activated carbon is determined by moisture content, iodine adsorption, methylene blue adsorption, color, surface area, and volume of pores. In this research, two of quality analyses are done. That is moisture content and iodine adsorption. The presence of water in the activated carbon relating to hygroscopic nature, wherein activated carbon has a great affinity to water. This calls for moisture content. Because of this hygroscopic properties, betel nuts activated carbon is used as the adsorbent. The moisture content of 18 mesh betel nuts activated carbon results $2.98 \%$. This point is compliance with quality standards based on SNI 063730-1995, where the maximum moisture content of granular activated carbon is $4.5 \%$.

The purpose of moisture content test is to determine the amount of water remains in the activated carbon after going through the activation process. Water molecules contained in the activated carbon will affect the absorption rate because the water molecules that bound to the activated carbon will cover the pores. Large pores will increase surface area which means increase its ability to adsorb.

Adsorption testing of iodine on activated carbon occurs to determine the activated carbon ability to adsorb molecules that have a small diameter and determine the ability to adsorb the color solution. Gimenes (2013) described adsorption of iodine indicates the ability of carbon to adsorb low molecular weight component. Hydrocarbon compound that remains on the surface of activated carbon will reduce adsorption ability. Laboratory analyses of adsorption of iodine obtain $485.85 \mathrm{mg} / \mathrm{g}$. This number is below the quality standards according to SNI 06-3730-1995 which at least $750 \mathrm{mg} / \mathrm{g}$. The iodine adsorption is changing rapidly. So, it could be an error in analyzation. This iodine absorption number must be analyzed at a laboratory with ISO certified to get the right measurements.

One of the indicators that can be used to determine water quality is COD value. The content of chemical oxygen demand in jumputan wastewater is analyzed with volumetry method appropriate with SNI 6989.2-2009. The content of COD is shown in Table 1 as follows:

Table 1. Chemical Oxygen Demand (mg/L)

\begin{tabular}{|c|c|c|c|c|c|c|}
\hline \multirow{2}{*}{$\begin{array}{c}\text { Height of } \\
\text { Bed (cm) }\end{array}$} & \multicolumn{6}{|c|}{ Sampling Time (minutes) } \\
\cline { 2 - 7 } & 0 & 30 & 60 & 90 & 120 & 150 \\
\hline 5 & 640 & 119.5 & 35 & 2 & 16 & 28 \\
\hline 15 & 640 & 70 & 15 & 30 & 26 & 2 \\
\hline 25 & 640 & 80 & 37 & 75 & 88.5 & 2 \\
\hline
\end{tabular}

According to [2], maximum COD threshold allowed is $150 \mathrm{mg} / \mathrm{L}$. Based on the preliminary test, COD level of Jumputan wastewater before treatment is $640 \mathrm{mg} / \mathrm{L}$ (time sampling 0 minutes). This value is four times greater than the threshold of COD in textile waste allowed. That value indicates there are a lot of organic and inorganic matters in the water. So, appropriate treatment to reduce the COD content is needed.

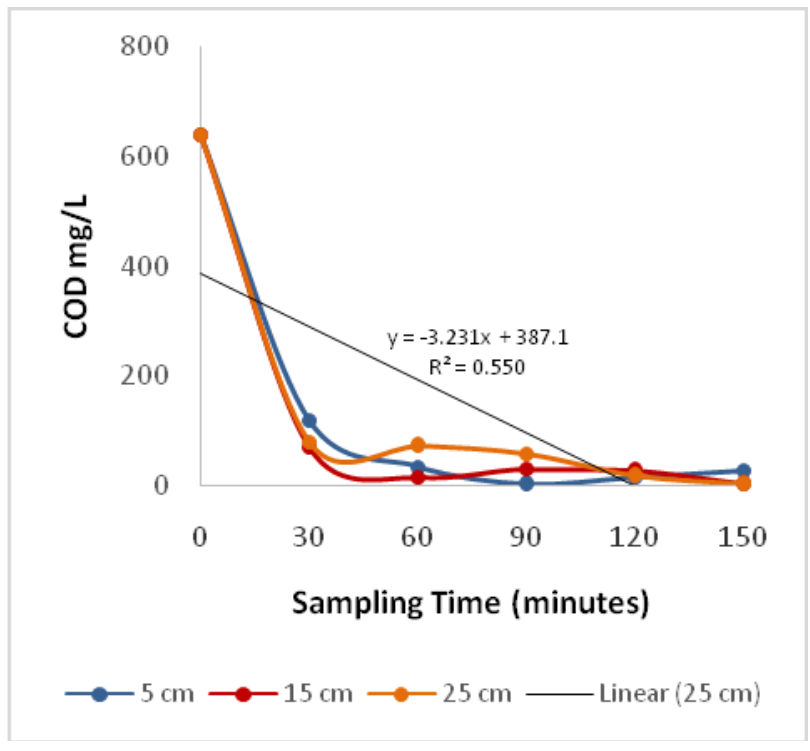

Fig. 2. COD remain in Jumputan liquid waste

One of the treatments is adsorption process by using continuous fixed-bed adsorber. Betel nuts activated carbon is placed in bed inside the column as an adsorbent. In this research, there is three factors influence adsorption, that is the amount of adsorbent, the surface area of adsorbent, and contact time. The amount of activated carbon is comparable to the bed height. The higher bed contains more activated carbon. Therefore bed height is varied $(5,15$, and $25 \mathrm{~cm})$. The size particle of betel nuts activated carbon is uniform (18 mesh 
sieved). Variation of contact time between jumputan liquid waste and betel nuts adsorbent is applied. Those are $30,60,90,120$, and 150 minutes. The relationship between the height of the bed and sampling time with COD remain in the waste is shown in Figure 2.

The relationship between the height of the bed and sampling time with COD remain in the waste is shown in Figure 2. The relationship between the height of the bed and sampling time with remaining COD in wastewater is fluctuating. By using $5 \mathrm{~cm}$ bed height, optimum COD remaining occurs at sampling time 90 minutes with COD measurement $2 \mathrm{mg} / \mathrm{L}$. At 15 and $25 \mathrm{~cm}$ bed height, optimum COD remain in jumputan waste is $2 \mathrm{mg} / \mathrm{L}$ with the sampling time of 150 minutes. Based on table 1 , all of the COD remaining after adsorption process in the jumputan liquid waste have met the standard wastewater characteristics as mentioned in Minister of Environment pursuant regulation No. 5 of 2014 that constrain maximum eligible COD discharged is $150 \mathrm{mg} / \mathrm{L}$.

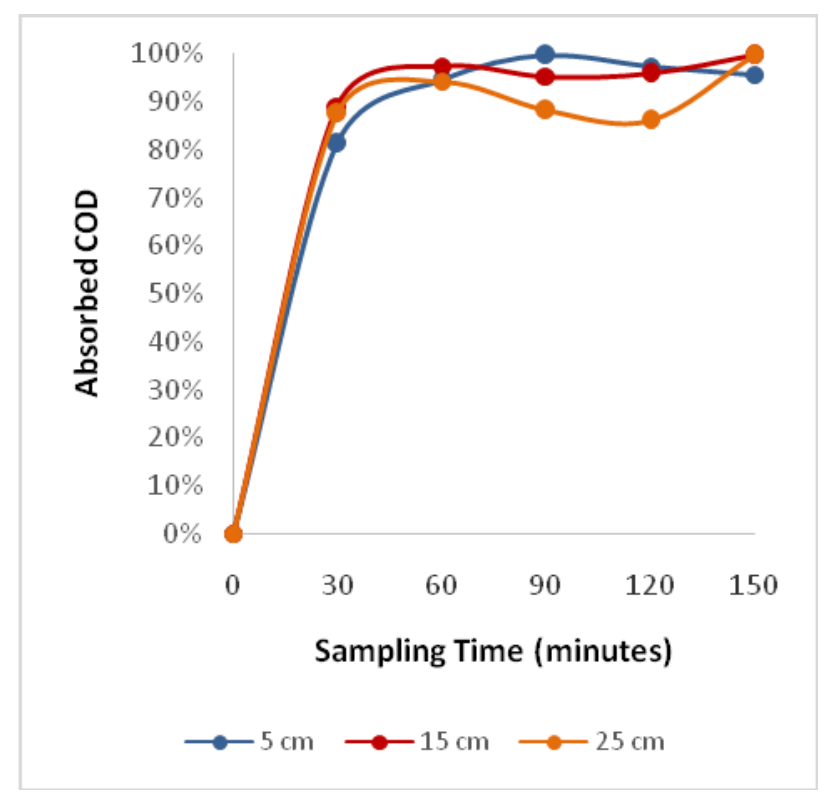

Fig. 3. Percentage of Adsorbed COD

Figure 3 shows the percentage of adsorbed COD. From the graph can be seen that the highest COD adsorbed is the bed with $5 \mathrm{~cm}$ high and 90 minutes sampling time, with amount $99.69 \%$. In 15 and $25 \mathrm{~cm}$ bed height, the percentage of COD adsorbed at 150 minutes sampling time generated optimum condition with an amount equal to $99.69 \%$. Compared with a previous study conducted by [7], this value is better. They obtained COD absorption percentage of $98.6111 \%$. From the two differences of absorbed COD percentage even with batch or continuous process surely that betel nuts activated carbon has ability to adsorb organic and inorganic components in jumputan liquid waste.

Factor that can reduce the content of COD in industrial wastewater is the quality and quantity of activated carbon. The quality of activated carbon is showed by water content and iodine adsorption. The water content of betel nuts activated carbon is appropriate with a standard. In another word, the activated carbon is good adsorbent. Higher percentages of adsorbed COD also indicate a higher quality of activated carbon. Compared with [1], [7], [9], and [10], removed COD on Jumputan wastewater by betel nuts activated carbon is the highest.

The quantity of activated carbon is directly proportional to the height of the bed and contact time between the adsorbent and jumputan wastewater. The highest bed will be placed by the most of the activated carbon, which means the best height of the bed is $25 \mathrm{~cm}$ due to its ability to adsorb COD component. Adsorption process in packed bed column is largely dependent on bed height [20]. This research results suitable with that statement. From linearity in figure 2., the best height of the bed is $25 \mathrm{~cm}$ with linear equation $\mathrm{y}=-3.231 \mathrm{x}+$ 387.1 with a correlation coefficient $(\mathrm{R})$ is 0.550 . $\mathrm{R}$ value for 5 and $15 \mathrm{~cm}$ height bed is smaller than 0.550 .

Contact time between the adsorbent and jumputan liquid waste can be seen from sampling time. In this investigation, the time limited to 150 minutes. Activated carbon efficiency decline with time addition [21]. Degradation ability of activated carbon to adsorb organic and inorganic components due to the pores on the surface of carbon has saturated. At 150 minutes, with 25 $\mathrm{cm}$ bed height, COD degrades from $640 \mathrm{mg} / \mathrm{L}$ to $2 \mathrm{mg} / \mathrm{L}$. From figure 2., COD continuously declines from its original. To get the whole description of COD reduction, time contact must be added. That means the activated carbon used has not reached saturation yet. The 150 minutes sampling time indicates that betel nuts activated carbon has a long lifetime.

\section{Conclusion}

Betel nuts activated carbon has ability to adsorb organic and inorganic components in jumputan liquid waste. Optimum variable to reduce COD in Jumputan waste liquid is $25 \mathrm{~cm}$ bed height and 150 minutes sampling time. Depreciation of COD value is $99.69 \%$ from its original.

The financial support given by Engineering Faculty of Universitas Sriwijaya, Palembang, Indonesia for this research work is gratefully acknowledged

\section{References}

1. T. E., Agustina, \& M., Amir, J. Teknik Kimia Universitas Sriwijaya 18, 3, 54-61 (2012)

2. B., Kambuaya, Kementrian Lingkungan Hidup, Indonesia (2014)

3. Kamsari, Center of Marine and Coastal Resources Institut Pertanian Bogor, Retrieved februari 12, 2016, from Institut Pertanian Bogor: www.pkspl.ipb.ac.id (2015, april 25)

4. S., Novita, Universitas Sumatera Utara, Retrieved februari 16, 2016, from Universitas Sumatera Utara: www.repository.usu.ac.id (2013)

5. Q., Yang, Z., Liu \& J., Yang, J. Water and Protection , 286-289 (2009)

6. M., Rahbar, E., Alipour \& R., Sedighi, 
International J. of Environment Science and Technology, 3, 1, 79-88 (2006)

7. L., Cundari \& dkk., Added Value of Energy Resources, Palembang: Universitas Sriwijaya (2015)

8. A., Nurfitriyani \& dkk., J. Online Institute Teknologi Nasional, 1, 2 (2013)

9. T. E., Agustina \& dkk., Added Value of Energy Resources (AVoER), 260-266, Palembang: Universitas Sriwijaya (2011)

10. N., Yuliasari, Miksusanti, \& E., Setiyowati, J. Penelitian Sains , 14 (1(C)), 29-32 (2011)

11. Riyanto, J. Kimia, 1-9 (2010)

12. Yuliusman \& Adelina, Seminar Rekayasa Kimia dan Proses, Depok: Universitas Indonesia (2010)

13. A., Surest \& dkk., J. Teknik kimia, 17-22 (2008)

14. F., Ramdja \& dkk., J. Teknik Kimia , 14 (4), 1-7 (2008)
15. A., Astuti, Semarang: Universitas Dipenegoro (2007)

16. Y., Danarto \& E. K., Artati, EKUILIBRIUM, 4 (2), 86-91 (2005)

17. M. A., Fauziah \& dkk., Semarang: Universitas Diponegoro (2014)

18. H., Halim \& K., Mee, International Conference on Enviromental and Industrial Innovation, IPCBEE , 12, 263-267 (2011)

19. M. L., Gimenes, AIDIC, 32, 2023-2028 (2013)

20. Ikawati dan Melati, Jurusan Teknik Kimia, Fakultas Teknik, Universitas Diponegoro (2010)

21. S., Sughashini \& K., Begum, J. of Chemistry, 1-11 (2012)

22. R. D., Siregar, T. A., Zaharah \& N., Wahyuni, JKK, 62-66 (2015) 